\title{
Novel histone deacetylase inhibitor exhibits antitumor activity via apoptosis induction in oral squamous cell carcinoma
}

\author{
Osamu Takahashi ${ }^{12^{*}}$, Toshinori Okinaga ${ }^{1}$, Kenjiro Iwanaga ${ }^{2}$, Manabu Habu $^{2}$, Wataru Ariyoshi $^{1}$, \\ Kazuhiro Tominaga ${ }^{2,4}$, Norikazu Nishino ${ }^{3}$, Tatsuji Nishihara ${ }^{1,4}$ \\ ${ }^{1}$ Department of Health Promotion, Division of Infections and Molecular Biology, Kyushu Dental College, Kitakyushu, Japan; \\ *Corresponding Author: tatsujin@kyu-dent.ac.jp \\ ${ }^{2}$ Department of Oral and Maxillofacial Surgery Division of Maxillofacial Diagnostic and Surgical Science, Kyushu Dental College, \\ Kitakyushu, Japan; \\ ${ }^{3}$ Graduate School of Life Science and Systems Engineering, Kyushu Institute of Technology, Kitakyushu, Japan; \\ ${ }^{4}$ Oral Bioresearch Center, Kyushu Dental College, Kitakyushu, Japan.
}

Received 22 May 2011; revised 17 June 2011; accepted 5 July 2011.

\begin{abstract}
Epigenetic modifications such as histone deacetylation are commonly related to tumor development and histone deacetylase (HDAC) inhibitors have been shown to be potential drugs for cancer treatment. In the present study, we investigated the effects of a novel HDAC inhibitor, $\mathrm{Ky}-2$, on oral squamous carcinoma cells in vitro. Cell viability was significantly reduced by treatment with $\mathrm{Ky}-2$ at $25 \mathrm{nM}$, while it also led to augmentation of the proportion of cells in the sub-G1 phase and DNA fragmentation. In addition, immunoblot analysis revealed that $\mathrm{Ky}-2$ enhanced the expression of apoptosis-related proteins. Our results showed that a low concentration of $\mathrm{Ky}-2$ induced apoptosis in oral squamous carcinoma cells via activation of apoptotic cascades.
\end{abstract}

Keywords: Histone Deacetylase Inhibitor; Apoptosis; Squamous Cell Carcinoma;

Hydroxamic Acid

\section{INTRODUCTION}

Oral cancer, especially oral squamous cell carcinoma, is a major cause of cancer-related death that affects nearly 500,000 patients annually worldwide. Three major modalities, surgery, irradiation, and chemotherapy, are widely applied as conventional treatment strategies for oral cancer. Of those, chemotherapy is beneficial for local tumor control and survival improvement, and also has advantages of avoiding esthetic and functional dis- turbances associated with surgical treatments. However, therapeutic agents are needed to improve the results of conventional chemotherapies for oral cancer [1,2].

When histone deacetylase (HDAC) function is inhibited, histones remain to be acetylated, resulting in more open chromatin conformation, which facilitates the transcription of genes [3]. Histone deacetylase has recently attracted much attention as an epigenetic factor, and it has been shown that modulation of the acetylation status of histones and transcription factors is important for regulating gene expression [4]. HDAC inhibitor treatment has been found to augment the expression of genes such as apoptotic factors related to both extrinsic and intrinsic pathways, cell cycle suppressors, and angiogenic factors [5,6].

At the time of writing, the Unite States Food and Drug Administration has approved 2 HDAC inhibitors, vorinostat and romidepsin, for treatment of manifestations of cutaneous T-cell lymphoma [7]. However, validated HDAC inhibitors for the treatment of solid tumors remain to be developed.

In the present study, we examined the cytotoxic effects of a novel HDAC inhibitor on cancer cells and clarified the mechanism by which it induces apoptosis in oral squamous carcinoma cells.

\section{MATERIALS AND METHODS}

\subsection{Cell Culture}

Ca9-22, a human gingival squamous carcinoma cell line, was maintained in RPMI 1640 (GIBCO BRL, Grand Island, NY, USA) with 10\% heat-inactivated fetal bovine serum, penicillin $(100 \mathrm{U} / \mathrm{ml})$, and streptomycin 
$(100 \mu \mathrm{g} / \mathrm{ml})$ at $37^{\circ} \mathrm{C}$ in $5 \% \mathrm{CO}_{2}$ and air.

Cyclic hydroxamic acid-containing peptide (CHAP)15, renamed Ky-2, cyclo (Asu(NHOH)-Aib-Phe-D-Pro), and suberoylanilide hydroxamic acid (SAHA; Cayman Chemical, Ann Arbor, MI, USA) (Figure 1(a)) [8] were prepared as stock solutions at concentrations of 80 and $75 \mathrm{mM}$, respectively. The caspase-9 inhibitor benzyloxycarbonyl-Leu-Glu(OMe)-His-Asp(OMe)-CH2F (ZLEHD-fmk), was purchased from Calbiochem Co. (San Diego, CA, USA).<smiles>CC1(C)NC(=O)C(CCCCCC(=O)NO)NC(=O)C(Cc2ccccc2)NC(=O)C(=O)CCCC1=O</smiles>

Ky-2

(a)

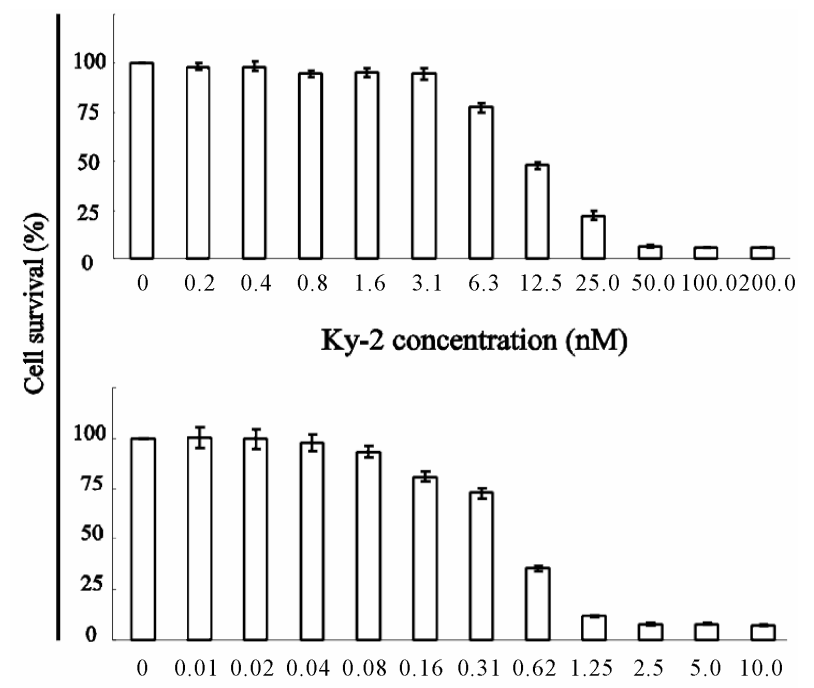

SAHA concentration $(\mu \mathrm{M})$

(b)

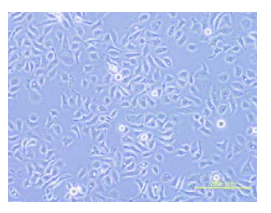

Non-treated

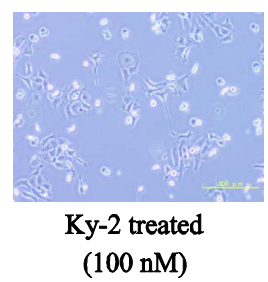

(c)

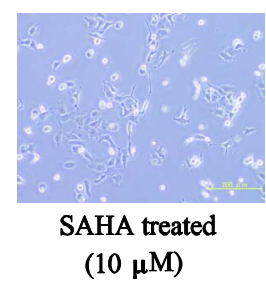

$(10 \mu \mathrm{M})$
Figure 1. Chemical structure and biological activity of Ky-2. (a) Chemical structures of Ky-2 and SAHA; (b) Effects of Ky-2 and SAHA on viability of Ca9-22 cells. Ca9-22 cells were treated with $\mathrm{Ky}-2(0.2-200 \mathrm{nM})$ or SAHA $(0.01-10 \mu \mathrm{M})$ for 48 hours, and cell viability was assessed using a WST-1 assay; (c) Morphological changes in Ca9-22 cells treated with $\mathrm{Ky}-2$. Cells were treated with $\mathrm{Ky}-2$ (100 nM) or SAHA (10 $\mu \mathrm{M}$ ) for 48 hours, and examined with light microscopy (IX71; OLYMPUS, Tokyo, Japan).

\subsection{In Vitro Cell Proliferation Assay}

Cell proliferation was evaluated using a colorimetric WST-1 assay. Ca9-22 cells were seeded in flat-bottomed 96-well plates at a concentration of $1 \times 10^{4}$ cells $/ \mathrm{ml}$. After the cells were treated with $\mathrm{Ky}-2$ for 44 hours, $10 \mu \mathrm{l}$ of WST-1 reagent (Dojindo, Kumamoto, Japan) was added to each well followed by incubation for 4 hours. Absorbance at $450 \mathrm{~nm}$ was measured using a Multiskan JX microplate reader (Thermo Fisher Scientific, Rockford, IL, USA)

\subsection{Light Microscopy}

After treatment with Ky-2 or SAHA for 24 hours, Ca9-22 cells were examined under a light microscope (IX71; OLYMPUS, Tokyo, Japan) for changes in cell morphology and photographs were obtained using a DP71 (OLYMPUS, Tokyo, Japan).

\subsection{Immunofluorescence and Confocal Microscopic Analysis}

For immunofluorescence analysis, cells were cultured in 8-well Lab-Tek ${ }^{\mathrm{TM}}$ chamber slides (Nagle Nunc International, Rochester, NY, USA) at a density of $1 \times 10^{4}$ cells/well. After Ky-2 (100 nM) treatment for 3 hours, cells were fixed with $4 \%$ formaldehyde, then permeabilized with $0.2 \%$ Triton X-100 in phosphate buffered saline (PBS, $\mathrm{pH}$ 7.2) for 15 minutes at room temperature. After blocking with $1 \%$ bovine serum albumin (BSA) in $\mathrm{PBS}$, the slides were treated overnight at $4^{\circ} \mathrm{C}$ with rabbit polyclonal antibodies against acetyl-histone H3 (Lys14) (1:1000; Cell Signaling Technology, Beverly, MA, USA), then washed and treated with goat anti-rabbit IgG antibody Alexa Fluor ${ }^{\circledR} 488$ (1:200; Molecular Probe, Invitrogen, Carlsbad, CA, USA) for 2 hours at room temperature, followed by the addition of an actin staining reagent, Alexa Fluor ${ }^{\circledR} 568$ phalloidin (1:40; Molecular Probe, Invitrogen, Carlsbad, CA, USA). Cells were visualized with a Fluorescence Microscope BZ-9000 (KEYENCE CORP., Osaka, Japan). Images were captured digitally in real time and processed using BZ-II imaging software (KEYENCE CORP., Osaka, Japan).

\subsection{Immunoblot Analysis}

The samples were lysed in SDS lysis buffer (50 mM Tris-HCl, 2\% SDS; pH 6.8). The protein contents were determined using a protein assay reagent (Bio-Rad Laboratories, Hercules, CA, USA). Each protein sample (30 $\mu \mathrm{g})$ was subjected to electrophoresis on a $7.5 \%$ or $15 \%$ SDS-polyacrylamide gel, and electro-blotted onto a PVDF membrane. After incubation with 5\% non-fat skim milk in PBS containing 0.1\% Tween-20 for 1 hour, 
the membranes were treated with the primary antibody, as described below. Polyclonal antibodies against acetyl-histone H3 (Lys14), lamin A/C, poly (ADP-ribose) polymerase (PARP), caspase-3, caspase-6, and caspase-7 were purchased from Cell Signaling Technology (Beverly, MA, USA), while a monoclonal antibody against caspase-9 was purchased from Medical \& Biological Laboratories (Woburn, MA, USA) and a polyclonal antibody against Actin (C-2) was purchased from Santa Cruz Biotechnology (Santa Cruz, CA, USA). Immunodetection was performed using an ECL-plus Western blotting detection system (Amersham Bioscience, Little Chalfont, Buckinghamshire, UK) according to the manufacturer's instructions. The band densities were measured with a Molecular Imager ${ }^{\circledR}$ ChemiDocTM XRS Plus system (Bio-Rad Laboratories, Hercules, CA, USA). Blots were stained with Coomassie Brilliant Blue and each lane was confirmed to contain a similar amount of protein extract.

\subsection{Detection of Apoptotic Cells}

Ca9-22 cells were suspended in a hypotonic solution (0.1\% Triton X-100, 1 mM Tris-HCl; pH 8.0), 3.4 mM sodium citrate, $0.1 \mathrm{mM}$ ethylenediaminetetraacetic acid) and stained with $5 \mu \mathrm{g} / \mathrm{ml}$ of propidium iodide (PI), then analyzed with a FACScalibur flow cytometer (EPICS XL; Beckman Coulter, Fullerton, CA, USA). For Annexin $\mathrm{V}$ and PI staining, Ca9-22 cells were washed with PBS and resuspended in binding buffer (10 mM HEPES, $140 \mathrm{mM} \mathrm{NaCl}, 2.5 \mathrm{mM} \mathrm{CaCl}$; pH 7.4). Fluoresceinconjugated Annexin V and PI solutions were added, and mixed gently according to the manufacturer's instructions (Molecular Probe, Invitrogen, Carlsbad, CA, USA). Cells were incubated at room temperature and then analyzed with an EPICS XL. To detect apoptotic nuclei, Ca9-22 cells were fixed with $1 \%$ glutaraldehyde for 1 hour, washed with PBS, and stained with $1 \mathrm{mM}$ of Hoechst dye 33342 (Ana Spec, Fremont, CA, USA). Nuclei were visualized by fluorescence microscopy (BX51; OLYMPUS, Tokyo, Japan), with an excitation wavelength of $355 \mathrm{~nm}$ and emission wavelength of $465 \mathrm{~nm}$.

\subsection{Statistical Analysis}

All experiments were performed 3 times and the results are presented as the mean \pm standard deviation (S.D) of each.

\section{RESULTS}

\subsection{Ky-2 Inhibits Growth of Ca9-22 Cells}

We investigated the effects of Ky-2 on the viability of Ca9-22 cells using a WST-1 assay. As shown in Figure 1(b), Ky-2 dose-dependently inhibited cell proliferation with estimated half maximal inhibitory concentrations ( $\mathrm{IC}_{50}$ ) ranging from 12.5 to $25.0 \mathrm{nM}$. In contrast, SAHA had a lower effect on the growth of Ca9-22 cells. Both $\mathrm{Ky}-2$ and SAHA induced a significant decrease in the number of viable cells as compared with the control, and also caused dramatic changes to the cells to develop an elongated shape with filamentous protrusions (Figure 1(b)).

\subsection{Acetylation of Histone $\mathrm{H3}$}

To clarify whether $\mathrm{Ky}-2$ is an effective inhibitor of HDAC enzymes in Ca9-22 cells, we examined the acetylation of histone $\mathrm{H3}$ by immunoblot analysis. Histone H3 acetylation was expressed in Ca9-22 cells treated with $\mathrm{Ky}-2$, as shown by immunoblot analysis (Figure 2(a)), while immunofluorescence analysis showed that Ky-2 treatment enhanced that acetylation (Figure 2(b)).

\subsection{Detection of Apoptosis Cells}

When Ca9-22 cells were treated with Ky-2 (100 nM) for 24 hours, the percentage of cells in the sub-G1 phase was $32.9 \%$ (Figure 3(a)). To investigate the nature of Ca9-22 cell death following Ky-2 treatment, we analyzed the cells after exposing them to a combination of

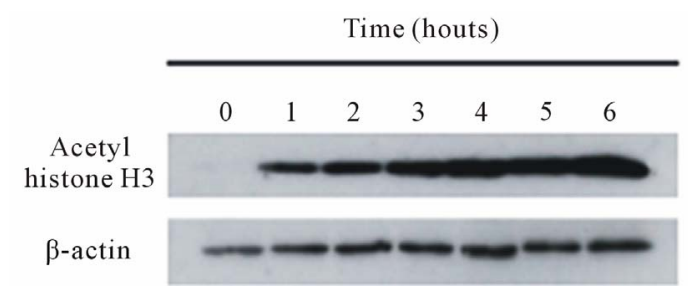

(a)

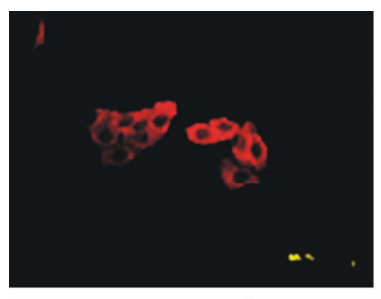

Non-treated

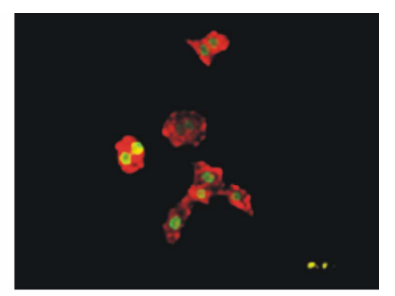

Ky-2 treated $(100 \mathrm{nM})$ (b)

Figure 2. Ky-2 induces acetylation of histone $\mathrm{H} 3$ in $\mathrm{Ca} 9-22$ cells. (a) Ca9-22 cells were treated with $\mathrm{Ky}-2$ (100 nM) for the indicated time periods. Expression of acetylated histone H3 was detected using immunoblotting analysis; (b) Confocal immunofluorescent analysis of Ca9-22 cells treated with Ky-2. Ca9-22 cells were treated with acetyl-histone H3 (Lys14) antibody and goat anti-rabbit IgG secondary antibody Alexa Fluor $^{\circledR} 488$, followed by addition of actin stain Alexa Fluor ${ }^{\circledR}$ 568 phalloidin. 

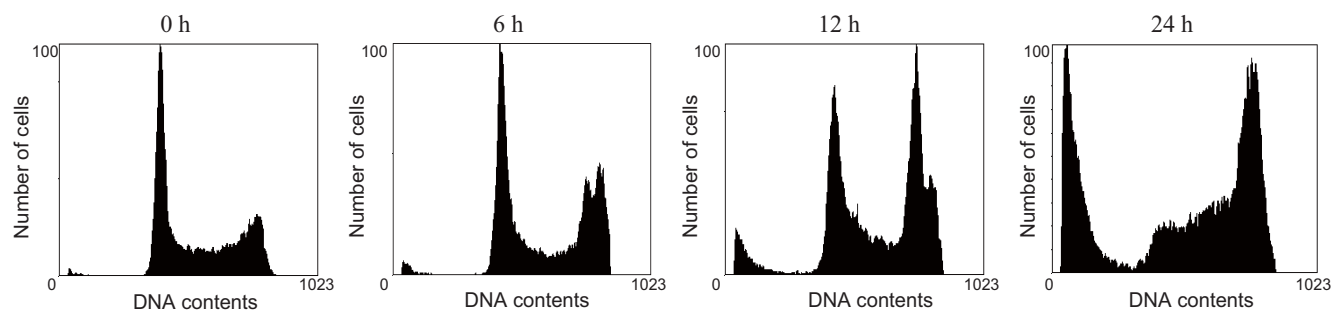

\begin{tabular}{|c|c|c|c|c|}
\hline Time & $0 \mathrm{~h}$ & $6 \mathrm{~h}$ & $12 \mathrm{~h}$ & $24 \mathrm{~h}$ \\
\hline Sub-G1 phase & $3.8 \%$ & $5.2 \%$ & $11.5 \%$ & $32.9 \%$ \\
\hline
\end{tabular}

(a)
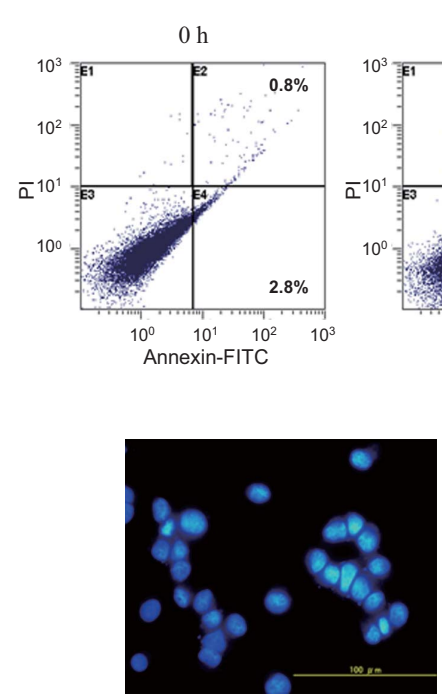

Non-treated
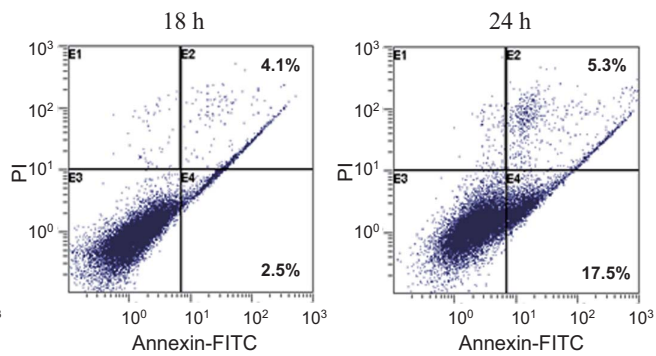

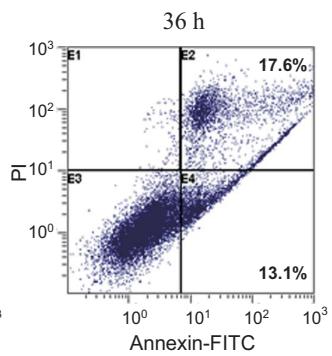

Annexin-FITC

(b)

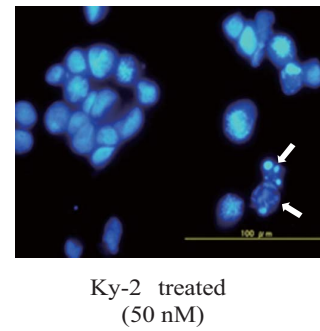

(c)

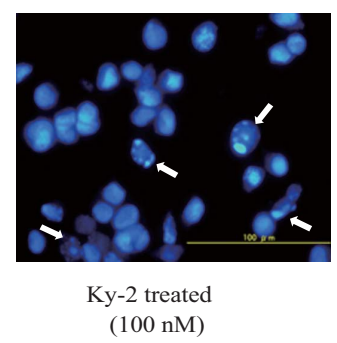

Ky-2 treated
$(100 \mathrm{nM})$

Figure 3. Detection of apoptosis in Ca9-22 cells treated with $\mathrm{Ky}-2$. (a) Ca9-22 cells were treated with Ky-2 (100 nM) for 6, 12, and 24 hours, and analyzed by flow cytometry; (b) Ca9-22 cells were treated with Ky-2 (100 nM) for 24 hours and stained with Annexin V/PI, and analysed by flow cytometry; (c) Ca9-22 cells were treated with $\mathrm{Ky}-2(100 \mathrm{nM})$ for 24 hours and stained with Hoechst's dye 33342. Apoptotic cells exhibiting characteristic chromatin condensation were observed by fluorescence microscopy $(\times 400)$. White arrows indicate apoptotic nuclei.

Annexin V and PI. Flow cytometric analysis revealed that $\mathrm{Ky}-2$ treatment enhanced the surface expression of phosphatidylserine after being cultured for 24 and 36 hours, as shown by an increase of Annexin $\mathrm{V}$ binding (Figure 3(b)). We also examined apoptotic nuclei in Ky-2-treated Ca9-22 cells using Hoechst's staining. As shown in Figure 3(c), apoptotic cells were indentified according to their characteristic cell morphology, such as condensation and degradation of the nuclei, after $\mathrm{Ky}-2$ treatment. Taken together, these results indicate that Ky-2 treatment induces apoptosis in Ca9-22 cells.

\subsection{Ky-2 Modulates Apoptosis-Regulatory Proteins}

To clarify the mechanism of the cytotoxic effects of
Ky-2 (100 nM) on Ca9-22 cells, we investigated the involvement of caspases in apoptotic cell death. Ca9-22 cells were treated with $\mathrm{Ky}-2$, and the expression of procaspase-9, -3, -6, and -7 were examined using immunoblot analysis. Procaspase-9, -3, -6, and -7 were detected in the cells as protein bands with a molecular mass of 45, 35, 35, and $35 \mathrm{kDa}$, respectively. Cleaved forms of caspase-9 (35 kDa), -3 (17 kDa), -6 (15 kDa) and $-7(20 \mathrm{kDa})$ were detected at 18 hours after $\mathrm{Ky}-2$ treatment (Figure 4). Furthermore, immunoblot analysis revealed that treatment with $\mathrm{Ky}-2$ caused cleavage of PARP, an enzyme involved in DNA repair, and a substrate for caspase- 3 and -7 , in a time-dependent manner as an $89-k D a$ fragment. Also, PARP-cleaved products appeared at 18 hours and their levels were increased 


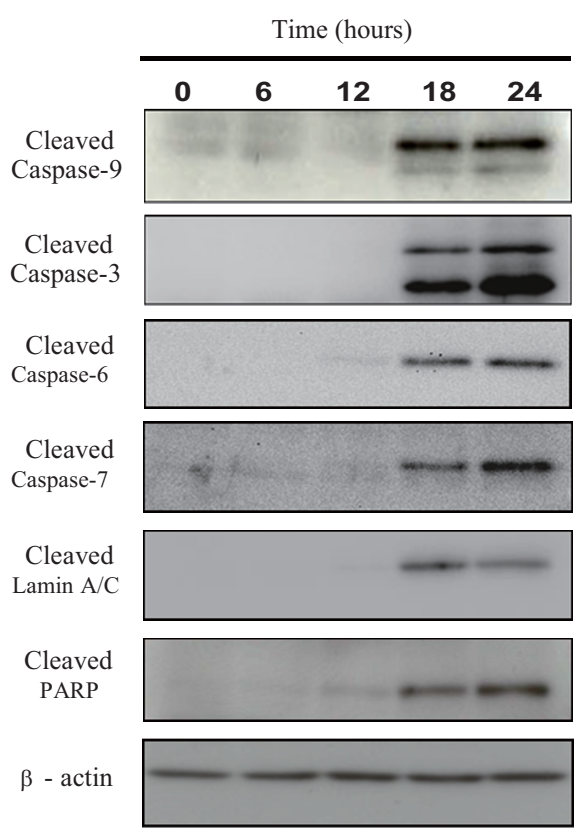

Figure 4. Expression of apoptosis-related proteins in Ca9-22 cells treated with $\mathrm{Ky}-2$. Ca9-22 cells were treated with Ky-2 (100 $\mathrm{nM})$ for the indicated time periods. Expressions of apoptosis-related proteins were detected by immunoblotting analysis.

after 24 hours (Figure 4). Proteolytic lamin A/C, a major structural protein of the nuclear envelope and substrate for caspase-6, was cleaved as a small (28 kDa) fragment at 18 hours after $\mathrm{Ky}-2$ treatment.

\subsection{Effect of Caspase-9 Inhibitor on $\mathrm{Ky}-2$ Induced Apoptosis}

Next, we examined the effect of a caspase-9 inhibitor (Z-LEHD-fmk; $100 \mathrm{nM}$ ) on $\mathrm{Ky}$-2-induced apoptosis in Ca9-22 cells. When Ca9-22 cells were treated with Ky-2 (100 nM) for 24 hours, the percentage of cells in the sub-G1 phase was $32.9 \%$. On the other hand, when those cells were cultured with caspase- 9 inhibitor the percentage was $20.4 \%$, as shown by flow cytometric analysis (Figure 5(a)). At 18 hours after beginning Ky-2 treatment, the caspase- 9 inhibitor blocked the expressions of cleaved caspase-9, -3, -6, and -7 (Figure 5(b)). In addition, cleavage of lamin A/C and PARP were not detected in Ky-2 treated-cells incubated with caspase-9 inhibitor (Figure 5(b)).

\section{DISCUSSION}

A variety of HDAC inhibitors have been extensively developed as promising targets for cancer therapy $[9,10]$. Among them, hydroxamic acids, such as SAHA, have been found to cause differentiation, growth arrest, and apoptosis in a series of tumor cells, while normal cells were observed to be relatively resistant $[1,11,12]$. Notably, SAHA, clinically used as an HDAC inhibitor, was found to reduce tumor volume by $78 \%$ in animals, with no detectable toxic side effects [13]. In the present study, we used SAHA and a chlamydocin-hydroxamic acid analog, $\mathrm{Ky}-2$, as specific inhibitors of HDACs in order to investigate their antitumor effects on oral squamous carcinoma cells, Ca9-22 cells. Our results showed that $\mathrm{Ky}-2$ and SAHA each induced cell death in Ca9-22 cells in a dose-dependent manner, as well as accumulation of acetylated histone $\mathrm{H} 3$. It has been reported that the $\mathrm{IC}_{50}$ of SAHA ranges from 0.8 to $3.1 \mu \mathrm{M}$ with other head and neck squamous carcinoma cell lines $[4,14]$. Interesting, we found that Ky-2 inhibited the growth of Ca9-22 cells at nanomolar concentrations (Figures 1 and 2), suggesting that $\mathrm{Ky}-2$ is superior to SAHA as an antitumor agent.

$\mathrm{Ky}-2$ is synthesized by replacing the epoxyketone moiety of chlamydocin with hydroxamic acid [14]. The aliphatic chain of $\mathrm{Ky}-2$ may become inserted into the tube-like active-site pocket of HDACs, thereby chelating the zinc ion by the hydroxamic acid group at the bottom of the pocket, while the cyclic tetrapeptide structure confers a high affinity with HDAC. This high affinity is consistent with results of a model that showed that the cyclic tetrapeptide with hydrophobic groups serves as a cap for packing the inhibitor at the rim of the tube-like active-site pocket $[8,16,17]$. Taken together, these findings suggest that Ky-2 induces significant growth inhibition in Ca9-22 cells based on its characteristic structure (Figure 1(a)).

HDAC inhibitors are well known to induce growth inhibition and apoptosis in cancer cells [18]. The induction of apoptosis was reported to be accompanied by the appearance of floating cells with sub-G1 DNA content, positive annexin $\mathrm{V}$ staining, negative propidium iodide staining, and activation caspase, indicating the characteristics of apoptosis [19]. At 24 hours after Ky-2 treatment, Ca9-22 cells were induced to undergo apoptosis, as shown by the appearance of a sub-G1 cell population peak, at which time the percentage of cells in the sub-G1 phase was 32.9\% (Figure 3(a)). Furthermore, Ky-2induced apoptosis was accompanied by activation of caspase-9, $-3,-6$, and -7 , and cleavage of lamin $\mathrm{A} / \mathrm{C}$ and PARP. It has also been reported that proteolysis of lamins, major structural proteins of the nuclear envelope, causes cleaving of a small fragment during the induction of apoptosis. Furthermore, PARP is well known to be involved in DNA repair, predominantly in response to environmental stress. PARP is important for cells to maintain their viability, while its cleavage facilitates cellular disassembly and serves as a marker of cells undergoing apoptosis [20,21]. 

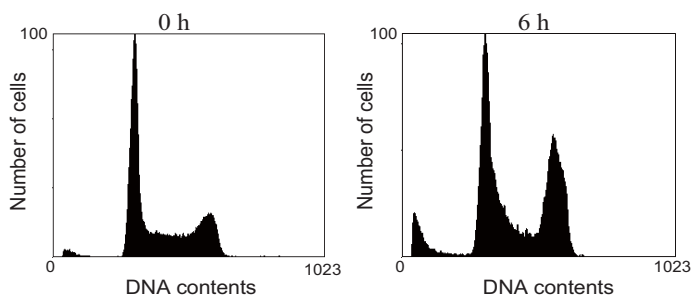

DNA contents

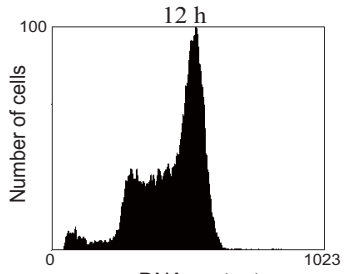

DNA contents

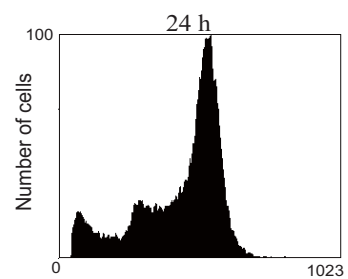

DNA contents

\begin{tabular}{|c|c|c|c|c|}
\hline Time & $0 \mathrm{~h}$ & $6 \mathrm{~h}$ & $12 \mathrm{~h}$ & $24 \mathrm{~h}$ \\
\hline Sub-G1 phase & $5.3 \%$ & $13.5 \%$ & $10.1 \%$ & $20.4 \%$ \\
\hline
\end{tabular}

(a)

\begin{tabular}{|c|c|c|c|}
\hline $\begin{array}{l}\text { Caspase-9 } \\
\text { inhibitor }\end{array}$ & - & - & + \\
\hline Ку-2 & - & + & + \\
\hline $\begin{array}{c}\text { Cleaved } \\
\text { Caspase-9 }\end{array}$ & & $=$ & D \\
\hline $\begin{array}{c}\text { Cleaved } \\
\text { Caspase-3 }\end{array}$ & & $\bar{a}$ & \\
\hline $\begin{array}{c}\text { Cleaved } \\
\text { Caspase- } 6\end{array}$ & & 10 & \\
\hline $\begin{array}{c}\text { Cleaved } \\
\text { Caspase-7 }\end{array}$ & & $=$ & \\
\hline
\end{tabular}

\begin{tabular}{|c|c|c|c|}
\begin{tabular}{|c|} 
Caspase-9 \\
inhibitor
\end{tabular} & - & - & + \\
\hline Ky-2 & - & + & + \\
\hline $\begin{array}{c}\text { Cleaved } \\
\text { Lamin A/C }\end{array}$ \\
$\begin{array}{c}\text { Cleaved } \\
\text { PARP }\end{array}$ \\
$\beta$-actin
\end{tabular}

(b)

Figure 5. Caspase-9 inhibitor suppressed Ky-2-induced apoptosis in Ca9-22 cells. (a) Ca9-22 cells were treated with Ky-2 (100 nM) in the presence of the caspase-9 inhibitor (Z-LEHD-fmk; $100 \mathrm{nM})$ for 6, 12, and 24 hours, and analyzed by flow cytometry; (b) Ca9-22 cells were treated with $\mathrm{Ky}-2$ (100 nM) in the presence of Z-LEHD-fmk $(100 \mu \mathrm{M})$ for 18 hours. Expressions of apoptosis-related proteins were detected by immunoblotting analysis.

In the present study, the activated cascade of caspase- 6 and -7 played a critical role in the degradation of lamin $\mathrm{A} / \mathrm{C}$ and PARP in apoptotic Ca9-22 cells treated with $\mathrm{Ky}-2$. Interestingly, the caspase-9 inhibitor decreased the percentage of Ca9-22 cells in the sub-G1 phase after treatment with Ky-2 (Figures 3 and 5). Caspase- 9 activates the effectors caspase- 3 and -7 , which then trigger cell fragmentation by cleaving selected cell death substrates and also process different caspases [22]. These findings suggest that $\mathrm{Ky}-2$ induces apoptosis in Ca9-22 cells through a typical caspase cascade.

In conclusion, our results show that the growth inhibition observed in oral squamous carcinoma cells in response to Ky-2 treatment is a result of its marked structural diversity and induction of apoptosis via activation of a caspase cascade. In addition, they indicate that therapy with Ky-2 might be a promising approach for treatment of oral squamous cell carcinoma.

\section{REFERENCES}

[1] Shen, J., Huang, C., Jiang, L., Gao, F., Wang, Z., Zhang, Y., Bai, J., Zhou, H. and Chen, Q. (2007) Enhancement of cisplatin induced apoptosis by suberoylanilide hy- droxamic acid in human oral squamous cell carcinoma cell lines. Biochemical Pharmacology, 73, 1901-1909. doi:10.1016/j.bcp.2007.03.009

[2] Nagumo, T., Takaoka S., Yoshiba, S., Ohashi, M., Shirota, T., Hatori, M., Isobe, T., Tachikawa, T. and Sintani, S. (2009) Antitumor activity of suberoylanilide hydroxamic acid against human oral squamous cell carcinoma cell lines in vitro and in vivo. Oral Oncology, 45, 766-770. doi:10.1016/j.oraloncology.2008.11.009

[3] Ouwehand, K., de Ruijter, A.J.M., Van Bree, C., Caron, H.N. and Van Kuilenburg, A.B.P. (2005) Histone deacetylase inhibitor BL1521 induces a G1-phase arrest in neuroblastoma cells through altered expression of cell cycle proteins. FEBS Letter, 579, 1523-1528. doi:10.1016/j.febslet.2005.01.058

[4] Gillenwater, A.M., Zhong, M. and Lotan, R. (2007) Histone deacetylase inhibitor suberoylanilide hydroxamic acid induces apoptosis through both mitochondrial and Fas (Cd95) signaling in head and neck squamous carcinoma cells. Molecular Cancer Therapeutics, 6, 29672975. doi:10.1158/1535-7163.MCT-04-0344

[5] Germain, C.T., O’Brien, A. and Dimitroulakos, J. (2010) Activating transcription factor 3 regulates in part enhanced tumour cell cytotoxicity of the histone deacetylase inhibitor M344 and cisplatin in combination. Cancer Cell International, 10, 32-43. doi:10.1186/1475-2867-10-32 
[6] Carew, J.S., Giles, F.J. and Nawrocki, S.T. (2008) Histone deacetylase inhibitors: Mechanisms of cell death and promise in combination cancer therapy. Cancer Letter, 269, 7-17. doi:10.1016/j.canlet.2008.03.037

[7] Tang, Y.A., Wen, W.L., Chang, J.W., Wei, T.T., Tan, Y.H.C., Salunke, S., Chen, C.T., Chen, C.S. and Wang, Y.C. (2010) A novel histone deacetylase inhibitor exhibits antitumor activity via apoptosis induction, F-Actin disruption and gene acetylation in lung cancer. PloS One, 5, e12417. doi:10.1371/journal.pone.0012417

[8] Furumai, R., Komatsu, Y., Nishino, N., Khochbin, S., Yoshida, M. and Horinouchi, S. (2001) Potent histone deacetylase inhibitors built from trichostatin A and cyclic tetrapeptide antibiotics including trapoxin. Proceedings of the National Academy of Sciences USA, 98, 87-92. doi:10.1073/pnas.011405598

[9] Kim, D.H., Kim, M. and Kwon, H.J. (2003) Histone deacetylase in carcinogenesis and its inhibitors as anticancer agents. Journal of Biochemistry and Molecular Biology, 36, 110-119. doi:10.5483/BMBRep.2003.36.1.110

[10] Jhonstone, R.W. (2002) Histone-deacetylase inhibitors: Novel drugs for the treatment of cancer. Nature Reviews Drug Discovery, 1, 287-299. doi:10.1038/nrd772

[11] Lee, J.H., Choy, M.L., Ngo, L., Foster, S.S. and Marks, P.A. (2010) Histone deacetylase inhibitor induces DNA damage, which normal but not transformed cells can repair. Proceedings of the National Academy of Sciences USA, 107, 14639-14644. doi:10.1073/pnas.1008522107

[12] Kelly, W.K., O’Connor, O.A., Krug, L.M., Chiao, J.H., Heaney, M., Curley, T., MacGregore-Cortelli, B., Tong, W., Secrist, J.P., Richardson, S.S., Chu, E., Olgac, S., Marks, P.A., Scher, H. and Richon, V.M. (2005) Phase I study of an oral histone deacetylase inhibitor, suberoylanilide hydroxamic acid, in patients with advanced cancer. Journal of Clinical Oncology, 23, 3923-3931. doi:10.1200/JCO.2005.14.167

[13] Johnstone, R.W. (2002) Histone-deacetylase inhibitors: Novel drugs for the treatment of cancer. Nature Reviews Drug Discovery, 1, 287-299. doi:10.1038/nrd772

[14] Huang, L. and Pardee, A.B. (2000) Suberoylanilide hydroxamic acid as a potential therapeutic agent for human breast cancer treatment. Molecular Medicine, 6, 849-866.

[15] Oiso, H., Furukawa, N., Suefuji, M., Shimoda, S., Ito, A., Furumai, R., Nakagawa, J., Yoshida, M., Nishino, N. and
Araki, E. (2010) The role of class I histone deacetylase (HDAC) on gluconeogenesis in liver. Biochemical Biophysical Research Communications, 404, 166-072. doi:10.1016/j.bbrc.2010.11.086

[16] Komatsu, Y., Tomizaki, K., Tsukamoto, M., Kato, T., Nishino, N., Sato, S., Yamori, T., Tsuruo, T., Furumai, R., Yoshida, M., Horinouchi, S. and Hayashi, H. (2001) Cyclic hydroxamic-acid-containing peptide 31, a potent synthetic histone deacetylase inhibitor with antitumor activity. Cancer Research, 61, 4459-4466.

[17] Finnin, M.S., Donigian, J.R., Cohen, A., Richon, V.M., Rifkind, R.A., Marks, P.A., Breslow, R. and Pavletich, N.P. (1999) Structures of a histone deacetylase homologue bound to the TSA and SAHA inhibitors. Nature, 401, 188-193. doi:10.1038/43710

[18] Peart, M.J., Tainton, K.M., Ruefli, A.A., Dear, A.E., Sedelies, K.A., O’Reilly, L.A., Waterhouse, N.J., Trapani, J.A. and Johnstone, R.W. (2003) Novel mechanisms of apoptosis induced by histone deacetylase inhibitors. Cancer Research, 63, 4460-4471.

[19] De Schepper, S., Bruwiere, H., Verhulst, T., Steller, U., Andries, L., Wouters, W., Janicot, M., Arts, J. and Van Heusden, J. (2003) Inhibition of histone deacetylases by chlamydocin induces apoptosis and proteasome-mediated degradation of surviving. Journal of Pharmacology and Experimental Therapeutics, 304, 881-888. doi:10.1124/jpet.102.042903

[20] Okinaga, T., Kasai H., Tsujisawa, T. and Nishihara, T. (2007) Role of caspases in cleavage of lamin A/C and PARP during apoptosis in macrophages infected with a periodontopathic bacterium. Journal of Medical Microbiology, 56, 1399-1404. doi:10.1099/jmm.0.47193-0

[21] Kok, S.H., Cheng, S.J., Hong, C.Y., Lee, J.J., Lin, S.K., Kuo, Y.S., Chiang, C.P. and Kuo, M.Y.P. (2005) Norcantharidin-induced apoptosis in oral cancer cells is associated with an increase of proapoptotic to antiapoptotic protein ratio. Cancer Letter, 217, 43-52. doi:10.1016/j.canlet.2004.07.045

[22] Henderson, C., Mizzau, M., Paroni, G., Maesyro, R., Schneider, C. and Brancolini, C. (2003) Role of caspases, $\mathrm{Bid}$, and p53 in the apoptotic response triggered by histone deacetylase inhibitors Trichostatin-A (TSA) and Suberoylanilide hydroxamic acid (SAHA). Journal of Biological Chemistry, 278, 12579-1258. doi:10.1074/jbc.M213093200 